\title{
Training: Can It Be a Tool to Boost Service-Oriented Citizenship Behaviors?
}

\author{
Aizzat Mohd. Nasurdin ${ }^{1}$, Noor Hazlina Ahmad ${ }^{1} \&$ Tan Cheng Ling ${ }^{2}$ \\ ${ }^{1}$ School of Management, Universiti Sains Malaysia, Penang, Malaysia \\ ${ }^{2}$ Graduate School of Business, Universiti Sains Malaysia, Penang, Malaysia \\ Correspondence: Tan Cheng Ling, Graduate School of Business, Universiti Sains Malaysia, 11800 Penang, \\ Malaysia. Tel: 60-4-653-2896. E-mail: tanchengling@usm.my
}

\author{
Received: December 5, 2013 Accepted: April 3, 2014 Online Published: May 30, 2014 \\ doi:10.5539/ass.v10n11p141 URL: http://dx.doi.org/10.5539/ass.v10n11p141
}

\begin{abstract}
In order to stay on top of the competition game, service providers need to encourage patterns of service-oriented behaviors that are bound to satisfy their customers. High quality service delivery by employees may be achieved through training. The present study aims at testing a model linking training and service-oriented organizational citizenship behaviors (SO-OCBs). A total of 290 customer-contact hotel employees participated in the survey. Data was analyzed using partial least squares (PLS). The results demonstrate that training had a direct impact on the specific dimensions of employees' service-oriented citizenship behaviors. The findings offered support for the validity of the social exchange theory in explaining the relationship between training and SO-OCBs within the context of a non-Western sample. In a practical sense, managers should be cognizant of the fact that existing employees should be given training especially on-the-job type on a regular basis to upgrade their job knowledge, skills, and competencies. Through training, employees are likely to become more motivated and more willing to engage in service-oriented behaviors that extend beyond their call of duty.
\end{abstract}

Keywords: hotel employees, service-oriented citizenship behavior, training

\section{Introduction}

Today, tourism is the most vibrant tertiary sector and has a strong hold on the Malaysian economy. The sector contributes RM74.6 billion to the country's Gross National Income (GNI) in 2012, compared to RM36.9 billion in year 2009 (Economic Transformation Program, 2013). This increase in income can be attributed to the surge in the number of tourist arrivals to Malaysia from 16.43 million in 2005 to approximately 25.03 million in 2012 (Tourism Malaysia, 2013). Malaysia's rich cultural heritage and history, food, friendly people, architectural monuments, hospitality and services are positive strengths for its tourism sector, which make it ahead of other developing economies. The growth of the tourism industry has stimulated the expansion of the hotel industry. Statistics on inbound tourism expenditures by products from 2005 to 2011 indicate that on average, tourists spent approximately 31 percent of their expenditures on accommodation services (Department of Statistics, 2012). As a result of this spending pattern, hotel establishments in Malaysia showed a growing trend. For instance, in 2010, there were 2,367 hotels as opposed to 2,724 hotels in 2012 (Tourism Malaysia, 2011; 2012). As the number of hotel establishments increases, competition becomes stronger. To succeed in such situations, hotels must be able to deliver excellent services to their customers. In fact, superior service quality has been recognized as the prime source of sustainable competitive advantage (Arnett, Laverie, \& McLane, 2002; Hartline \& Jones, 1996). Since service quality depends primarily on the effectiveness with which frontline employees deal with customers and clients (Morrison, 1996), one possibility that can be carried out by hotels would be for them to encourage their frontline employees to perform behaviors that go beyond their call of duty. For example, helping guests in finding their way around the hotel will delight guests and enhance their satisfaction. These behaviors, which are beyond those specified by formal job prescriptions, are known as organizational citizenship behaviors (OCBs).

Since OCBs offer a variety of functional outcomes especially to service firms, many studies have tried to identify its antecedents, which include among others, emotional intelligence (Ramachandran, Jordan, Troth, \& Lawrence, 2011); personality (Moon, Kamdar, Mayer, \& Takeuchi, 2008), role stressors (Eatough, Chang, Miloslavic, \& Johnson, 2011), justice (Fassina, Jones, \& Uggerslev, 2008), empowerment (Jiang, Sun, \& Law, 2011), job satisfaction (Murphy, Ahanasou, \& King, 2002), transformational leadership (Schlechter \& 
Engelbrecht, 2006), and leader-member exchange (Illies, Nahrgang, \& Morgeson, 2007). Most of the research on OCBs has been focusing on subjects drawn from North America and other Western countries. Unfortunately, little research effort has been devoted to specific organizational practices that may induce OCBs particularly within a newly industrialized South-East Asian country like Malaysia. Morrison (1996) highlighted the importance of an organization's human resource management (HRM) practices in creating a context that promotes greater OCBs from employees. This line of thought is also shared by other scholars (Rousseau \& Greller, 1994; Tsaur \& Lin, 2004) who argued that how an organization manages its human resources sets the tone and conditions for the employee-employer relationship. To the extent that an organization's HRM practices create a social exchange relationship (Blau, 1964), employees will be more likely to engage in discretionary behaviors like OCBs because such practices will propagate a sense of obligation on the part of the employee to reciprocate. In fact, employees' perceptions of their employing organization's HRM practices were found to be significantly related to customers' perceptions of service quality (Schneider \& Bowen, 1985). The authors explained that when employees feel well treated through their organization's HRM practices, they will be able to devote their efforts, energies, and other resources to effectively treat their customers, which in turn, lead to high service quality.

Le Pine, Erez, and Johnson (2002) in their review and meta-analysis of the organizational citizenship behavior construct highlighted that a large number of scholars have conceived OCB as consisting of several behavioral dimensions. The most common conceptualization of the OCB construct was proposed by Organ (1988), which was subsequently operationalized by Podsakoff, MacKenzie, Moorman, and Fetter (1990). In Malaysia too, publications that exist in this area (see for example, Hemdi, Nasurdin, \& Hamid, 2007; Ishak, Ansari, \& Ahmad, 2003; Nasurdin \& Ramayah, 2003) were based on Organ's (1988) five-dimensional taxonomy. In addressing previous gaps in the literature, Bettencourt, Gwinner, and Meuter (2001) advocated the need for more research on specific forms of OCBs such as service-oriented OCBs (SO-OCBs) involving customer-contact employees within the service context. The authors provided many reasons which include the intangible and non-standardized nature of services and the specific requirements needed by frontline employees as "boundary-spanners" for the organization. Given the paucity of research on SO-OCBs in a non-Western setting, and since training has been illustrated as a critical component of "best" HRM practices by successful hotel operators (Enz \& Siguaw, 2000), the objective of this study was to examine the impact of training on SO-OCBs among customer-contact hotel employees in Malaysia.

\section{Literature Review}

\section{1 $O C B$ and $S O-O C B$}

According to Organ (1988), OCB is a type of discretionary individual behavior that is crucial for organizational success but goes beyond an employee's formal role requirements. This definition suggests that such behavior is not directly rewarded or recognized by the formal structure of the organization. OCB consists of five dimensions including altruism, conscientiousness, sportsmanship, courtesy, and civic virtue (Organ, 1988). Although other taxonomies of OCBs have been suggested and operationalized (see LePine et al., 2002), Organ's (1988) five-dimensions remain a popular framework in most research settings. SO-OCB, on the other hand, has been broadly defined as discretionary behaviors performed by customer-contact employees in a service organization that surpass their formal role descriptions (Bettencourt \& Brown, 1997). This specific form of OCB is more appropriate given the special role played by service employees in dealing with customers and representing the organization to outsiders (Bettencourt et al., 2001; Borman \& Motowildo, 1993). According to Bettencourt et al. (2001), SO-OCBs comprise three dimensions: (1) loyalty; (2) service delivery; and participation. Loyalty OCBs relate to behaviors involving acting as advocates to outsiders not only of the organization's products and services, but also of its image. Participation OCBs relate to actions such as taking personal initiatives especially in communication, to improve their own service delivery and that of their organization and peers. Service delivery OCBs involves behaving in a conscientious manner in activities surrounding service delivery to customers. In the hotel environment where customer preferences are heterogeneous and fast-changing as asserted by Raub (2008), SO-OCBs are deemed important in improving not only customers' perception of service quality but also their satisfaction and loyalty.

\subsection{HRM Practices and Training}

In simple terms, Nickson (2007) defined HRM as a set of professional practices in managing people in the organization. Generally, among others, HRM activities include human resource planning, recruitment, selection, human resource development, compensation and benefits, safety and health, and employee relations. Scholars (Guest, 1997; Purcell \& Hutchison, 2007) agree that HRM practices provide functional outcomes to 
organizations through its effects on employees' attitudes and performance. Despite the growing attention on HRM practices in the hotel industry (Hoque, 1999), examinations on individual or bundles of HRM practices in the tourism and hospitality industry are regarded as underdeveloped in comparison to other industries (Kusluvan, Kusluvan, Ilhan, \& Buyruk, 2010). The present study is designed to address this limitation by focusing on individual HRM practices as potential predictors of SO-OCBs. For hotels, as a labor-intensive industry, having well-trained and motivated employees especially those at the frontlines are undeniably vital in delivering superior service (Wang, 2006).

Training has been regarded as an investment since it is considered the main pathway to form a pool of high quality human resources (Khanfar, 2011). According to Enz and Siguaw (2000), training helps employees to enhance their intrinsic motivation through their own competence. In addition, since the hospitality industry is well-known to encounter high employee turnover (Ma \& Qu, 2011), training serves as an essential management tool to upgrade customer-contact employees' service performance. This line of reasoning is further supported by Karatepe, Yavas, and Babakus (2007) who asserted that in the hotel industry, training of frontline employees is necessary as they can make or break any business. Through training, employees can better understand customers' needs and can align their delivery of service to address their customers' requirements. The invaluable role of training was further highlighted by Babakus, Yavas, and Karatepe (2008) who claimed that training of task-related skills helps reduce frontline employees' level of emotional exhaustion. According to the scholars, frontline service jobs are stressful due to the frequent interactions between the employees and their customers. When these workers failed to deliver during the service encounters, employees are likely to experience feelings of strain. Through training, employees will acquire the skills, knowledge, and competencies necessary in dealing with customers' needs and demands effectively, thereby, reducing the former feelings of frustration and exhaustion. Several empirical studies which have been undertaken in the hospitality and other service industries proffered support for the positive effect of training on frontline employees' attitudes and behaviors (Ashill, Carruthers, \& Krisjanous, 2006; Babakus, Yavas, Karatepe, \& Avci, 2003; Tang \& Tang, 2012; Tsaur \& Lin, 2004). Hence, the present study sought to focus on training and how it affects SO-OCBs of customer-contact hotel employees in Malaysia. Taking stock of the above discussion, the following hypothesis will be tested.

H1: Customer-contact employees' perception of training will be positively related to their SO-OCBs.

\section{Method}

\subsection{Sample and Data Collection Procedure}

Our research participants consisted of customer-contact employees attached to the food and beverage (now on referred to as F \& B) department of 29 large participating hotels located in three regions of Peninsular Malaysia. The directory of hotels in Malaysia published by the Ministry of Tourism (2012) was used to identify the hotels. We employed the "drop-off" and "pick-up" method to distribute our survey packets for hotels in the northern region. For other regions, the survey packages were sent and collected via mail. Each survey packet addressed to the HR managers of the respective hotels contains 10 questionnaires to be distributed to customer-contact employees working in the F \& B department. Two weeks were given to respondents to complete the questionnaires and return them to their $\mathrm{F} \& \mathrm{~B}$ manager who is responsible to collate all the questionnaires before returning them to the HR manager. All 290 completed questionnaires were found to be useable and later analyzed.

\subsection{Measures}

A questionnaire using a five-point Likert scale (" $1 "$ " = "strongly disagree" to " $5 "$ " = "strongly agree") was used to gather data. Training was assessed using 4 items adapted from Delery and Doty (1996) whereas SO-OCBs was gauged via 16 items adapted from the scale developed by Bettencourt et al. (2001).

\section{Results}

\subsection{Sample Profile}

Of the 290 respondents who completed the survey, $49.0 \%$ were males while $51.0 \%$ were females. Respondents' age ranged from 17 to 55 years with an average of 26.5 years. Malays (67.9\%), Chinese (14.8\%), Indians $(11.7 \%)$, and "others" (5.5\%) make up the sample. More than half of the sampled respondents were unmarried (61.7\%). The sample was dominated by secondary school leavers who hold either SPM/SPMV/STPM certificates $(75.9 \%)$. The average organizational tenure and job tenure for the sample were 3.8 years and 4.0 years respectively.

\subsection{Goodness of Measures}

The goodness of measures was tested based on its validity and reliability. As shown in Table 1, loadings for all 
items were greater than Chin's (1998) proposed minimum value of 0.70 . To assess convergent validity, the average variance extracted (AVE) was used as suggested by Hair et al. (2013). In our study, the AVE for training and the SO-OCB constructs were 0.785 and 0.773 respectively which exceeded the recommended value of 0.50 to justify using the construct as recommended by Barclay, Thompson, and Higgins (1995). Our composite reliability $(\mathrm{CR})$ values which reflect the internal consistency of the latent construct for training and SO-OCB constructs were 0.936 to 0.911 respectively which surpassed Fornell and Larcker's (1981) specified minimum value of 0.7 .

Table 1. Items loadings, composite reliability and the average variance extracted for the measurement model

\begin{tabular}{lllll}
\hline Construct & Items & Loadings & AVE & CR \\
\hline Training & hrm_train1 & 0.881 & 0.785 & 0.936 \\
& hrm_train2 & 0.894 & & \\
& hrm_train3 & 0.899 & & \\
& hrm_train4 & 0.869 & & 0.911 \\
SO-OCBs & Loyalty & 0.849 & 0.773 & \\
& Participation & 0.906 & & \\
\hline
\end{tabular}

Next, we proceeded to test the discriminant validity of the measures by assessing the correlations between the measures of potentially overlapping constructs. As portrayed in Table 2, the squared correlations for each construct was less than the AVE by the indicators measuring that construct indicating adequate discriminant validity.

Table 2. Discriminant validity of constructs

\begin{tabular}{ccc}
\hline & Training & SO-OCBs \\
\hline Training & $\mathbf{0 . 8 8 6}$ & \\
SO-OCBs & 0.707 & $\mathbf{0 . 8 7 9}$ \\
\hline
\end{tabular}

Note: Diagonals represent the square root of the average variance extracted while the other entries represent the correlations

As illustrated in Table 3, all indicators possessed outer loadings of 0.707 and higher, which exceeded the cut-off value of 0.70 (Hair et al., 2013). This indicates that the associated indicators have much in common, which is captured by the construct. Our result implies that the measurement model has adequate convergent validity. We also assess the construct's discriminant validity by examining the cross-loadings of the indicators. As shown in Table 3, all items possess sufficient discriminant validity as the loading for each construct is greater than all of its cross loadings (Chin, 1998; Hair et al., 2013). In sum, our measurement model demonstrated adequate convergent validity and discriminant validity. 
Table 3. Loadings and cross loadings

\begin{tabular}{lllll}
\hline & Training & Loyalty & Participation & Service Delivery \\
\hline hrm_train1 & $\mathbf{0 . 8 8 1}$ & 0.578 & 0.509 & 0.452 \\
hrm_train2 & $\mathbf{0 . 8 9 4}$ & 0.569 & 0.627 & 0.546 \\
hrm_train3 & $\mathbf{0 . 8 9 9}$ & 0.550 & 0.603 & 0.518 \\
hrm_train4 & $\mathbf{0 . 8 6 9}$ & 0.602 & 0.538 & 0.505 \\
So-ocb1 & 0.600 & $\mathbf{0 . 8 8 9}$ & 0.589 & 0.515 \\
So-ocb2 & 0.560 & $\mathbf{0 . 8 8 3}$ & 0.600 & 0.513 \\
So-ocb3 & 0.543 & $\mathbf{0 . 8 6 6}$ & 0.575 & 0.535 \\
So-ocb4 & 0.530 & $\mathbf{0 . 7 8 7}$ & 0.481 & 0.409 \\
So-ocb5 & 0.502 & $\mathbf{0 . 7 8 8}$ & 0.575 & 0.461 \\
So-ocb6 & 0.476 & 0.550 & $\mathbf{0 . 7 7 3}$ & 0.545 \\
So-ocb7 & 0.549 & 0.563 & $\mathbf{0 . 8 8 6}$ & 0.623 \\
So-ocb8 & 0.522 & 0.590 & $\mathbf{0 . 8 6 3}$ & 0.629 \\
So-ocb9 & 0.510 & 0.492 & $\mathbf{0 . 8 0 9}$ & 0.592 \\
So-ocb10 & 0.556 & 0.514 & $\mathbf{0 . 7 0 7}$ & 0.549 \\
So-ocb11 & 0.456 & 0.463 & 0.654 & $\mathbf{0 . 8 1 0}$ \\
So-ocb12 & 0.574 & 0.555 & 0.683 & $\mathbf{0 . 8 0 7}$ \\
So-ocb13 & 0.458 & 0.507 & 0.576 & $\mathbf{0 . 8 1 1}$ \\
So-ocb14 & 0.420 & 0.375 & 0.545 & $\mathbf{0 . 7 5 1}$ \\
So-ocb15 & 0.444 & 0.431 & 0.505 & $\mathbf{0 . 8 2 2}$ \\
So-ocb16 & 0.366 & 0.420 & 0.494 & $\mathbf{0 . 7 8 5}$ \\
\hline
\end{tabular}

Next, we proceeded to conceptualize SO-OCB as a second-order construct which comprises three first-order constructs (loyalty, participation, and service delivery). As depicted in Figure 1 , the $\mathrm{R}^{2}$ value was 0.510 suggesting that $51.0 \%$ of the variance in SO-OCBs can be explained by training.

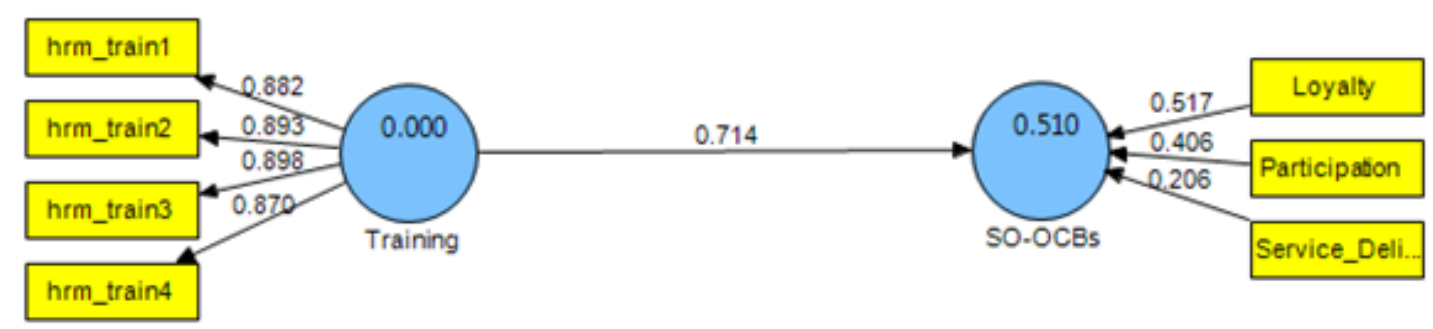

Figure 1. Measurement model with SO-OCB as a second order construct

Next, we proceeded with the path analysis to test our hypothesis. Table 4 depicts the results.

Table 4. Hypothesis testing

\begin{tabular}{llllll}
\hline Hypothesis & Relationship & Beta & Standard Error & t-value & Decision \\
\hline H1 & Training $->$ SO-OCBs & 0.714 & 0.029 & $24.881^{* *}$ & Supported \\
\hline Note: ${ }^{*} p<0.05 ;{ }^{* *} p<0.01$ & & & &
\end{tabular}


As shown in Table 4, training ( $\beta=0.714, \mathrm{p}<0.01)$ has a positive and significant effect on SO-OCBs, thereby, supporting $\mathrm{H} 1$.

\section{Discussion, Implications, and Limitations}

The purpose of this study was to examine the impact of training on SO-OCBs. The statistical results provide support for our hypothesized relationship. Our results demonstrate that greater perceptions of training have a significant effect on employees' SO-OCBs. Training provides employees with the opportunity to enhance their task-related skills and knowledge, which are relevant to their job performance. Through training, customer-contact employees would be able to better understand their customers and procure appropriate skills, attitudes, and behaviors necessary in the effective handling of customers' needs and requests. As a result, when customer-contact employees perceived that they receive extensive training, they are more likely to feel satisfied, less likely to experience frustration, which in turn, lead them to engage in more SO-OCBs. Our present finding concurs with previous researchers (see for example, Ashill et al, 2006; Babakus et al., 2003; Tsaur \& Lin, 2004). Our results also offer support for the validity of the social exchange theory (Blau, 1964) in explaining the relationship between training and SO-OCBs within the context of a non-Western sample.

Our findings appear to have some practical implications for hotels. Since perceptions of employees regarding the extent of training practices affect their SO-OCBs, it makes sense for hotel operators to impose some forms of formal training on their workers. Basic exposure involving practice sessions on proper ways to serve customers should be provided to new recruits during their orientation. Existing employees should also be given training especially on-the-job type on a regular basis to upgrade their job knowledge, skills, and competencies. Through training, employees are likely to become more motivated and more willing to engage in service-oriented behaviors that extend beyond their call of duty.

Our first limitation relates to the use of self-report measures of SO-OCBs which may contribute to common-method variance. To address this shortcoming, it may be worthwhile for future researchers to consider collecting data from multiple sources. Second, this study only deals with customer-contact employees working in hotels alone. Further testing this model in other service industries may help ascertain the efficacy of this model.

\section{Acknowledgements}

The authors would like to extend their gratitude to Universiti Sains Malaysia for providing the financial support (1001/PMGT/816193) to fund this research.

\section{References}

Arnett, D. B., Laverie, D. A., \& McLane, C. (2002). Using job satisfaction and pride as internal-marketing tools. Cornell Hotel and Restaurant Administration Quarterly, 43(2), 87-96. http://dx.doi.org/10.1016/S0010-8804(02)80035-0

Ashill, N., Carruthers, J., \& Krisjanous, J. (2006). The effect of management commitment to service quality on frontline employees' affective and performance outcomes: An empirical investigation of the New Zealand public healthcare sector. International Journal of Nonprofit and Voluntary Sector Marketing, 11(4), 271-287. http://dx.doi.org/10.1002/nvsm.281

Babakus, E., Yavas, U., \& Karatepe, O. M. (2008). The effects of job demands, job resources and intrinsic motivation on emotional exhaustion and turnover intentions: A study in the Turkish hotel industry. International Journal of Hospitality \& Tourism Administration, 9(4), 384-404. http://dx.doi.org/10.1080/15256480802427339

Babakus, E., Yavas, U., Karatepe, O. M., \& Avci, T. (2003). The effect of management commitment to service quality on employees' affective and performance outcomes. Journal of the Academy of Marketing Science, 31(3), 272-286. http://dx.doi.org/10.1177/0092070303031003005

Barclay, D. W., Thompson, R., \& Higgins, C. (1995). The partial least squares (PLS) approach to causal modeling: Personal computer adoption and use an illustration. Technology Studies, 2(2), 285-309.

Bettencourt, L. A., \& Brown, S. W. (1997). Contact employees: Relationships among workplace fairness, job satisfaction and prosocial service behaviors. Journal of Retailing, 73(1), 39-61. http://dx.doi.org/10.1016/S0022-4359(97)90014-2

Bettencourt, L. A., Gwinner, K. P., \& Meuter, M. L. (2001). A comparison of attitude, personality, and knowledge predictors of service-oriented organizational citizenship behaviors. Journal of Applied Psychology, 86(1), 29-41. http://dx.doi.org/10.1037/0021-9010.86.1.29

Blau, P. M. (1964). Exchange and Power in Social Life. New York: Wiley. 
Borman, W. C., \& Motowidlo, S. J. (1993). Expanding the criterion domain to include elements of contextual performance. In N. Schmitt, \& W. C. Borman (Eds.), Personnel selection (pp. 71-98). San Francisco: Josey-Bass.

Chin, W. W. (1998). The Partial Least Squares Approach for Structural Equation Modeling. United States: Lawrence Erlbaum.

Delery, J. E., \& Doty, D. H. (1996). Modes of theorizing in strategic human resource management: Tests of universalistic, contingency, and configurational performance predictions. Academy of Management Journal, 39(4), 802-836. http://dx.doi.org/10.2307/256713

Eatough, E. M., Chang, C-H., Miloslavic, S., \& Johnson, R. E. (2011). Relationships of role stressors with organizational citizenship behavior: A meta-analysis. Journal of Applied Psychology, 96(3), 619-632. http://dx.doi.org/10.1037/a0021887

Economic Transformation Program. (2013). Retrieved from etp.pemandu.gov.my

Enz, C., \& Siguaw, J. (2000). Best practices in human resources. Cornell Hotel and Restaurant Administration Quarterly, 4l(1), 48-61. http://dx.doi.org/10.1177/001088040004100123

Fassina, N. E., Jones, D. A., \& Uggerslev, K. L. (2008). Meta-analytic tests of relationships between organizational justice and citizenship behavior: Testing agent-system and shared variance models. Journal of Organizational Behavior, 29, 805-828. http://dx.doi.org/10.1002/job.494

Fornell, C., \& Larcker, D. F. (1981). Evaluating structural equation models with unobservable variables and measurement error. Journal of Marketing Research, 18(1), 39-50. http://dx.doi.org/10.2307/3151312

Guest, D. (1997). Human resource manage ment and performance: A review and research agenda. The International Journal of Human Resource Management, 8(3), 263-275. http://dx.doi.org/10.1080/095851997341630

Hair, J. F., Hult, G. T. M. Ringle, C. M., \& Sarstedt, M. (2013). A Primer on Partial Least Squares Structural Equation Modeling (PLS-SEM). United States: SAGE Publication, Inc.

Hartline, M. D., Jones, K. C. (1996). Employee performance cues in a hotel service environment: Influence of perceived service quality, value word of mouth intention. Journal of Business Research, 35, 207-215. http://dx.doi.org/10.1016/0148-2963(95)00126-3

Hemdi, M. A., Nasurdin, A. M., \& Hamid, M. A. (2007). Human resource management practices and organizational citizenship behavior: The mediational role of job satisfaction. The Proceedings of the $7^{\text {th }}$ Asian Academy of Management Conference. Penang, Malaysia.

Hoque, K. (1999). Human Resource Management in the Hotel Industry: Strategy, Innovation and Performance. London, GBR: Routledge.

Ilies, R., Nahrgang, J. D., \& Morgeson, F. P. (2007). Leader-member exchange and citizenship behaviors: A $\begin{array}{lllll}\text { meta-analysis. Journal of } & \text { Applied }\end{array}$ http://dx.doi.org/10.1037/0021-9010.92.1.269

Ishak, N. A., Ansari, M., \& Ahmad, Z. A. (2003). Leader member exchange and organizational citizenship behaviour: The mediating effect of self esteem. The Proceedings of the $5^{\text {th }}$ Asian Academy of Management Conference. Kuantan, Pahang, Malaysia.

Jiang, Y., Sun, L-Y., \& Law, K. S. (2011). Job satisfaction and organization structure as moderators of the effects of empowerment on organizational citizenship behavior: A self-consistency and social exchange perspective. International Journal of Management, 28(3), 675-693.

Khanfa, S. H. (2011). Impact of training on improving hotelling service quality. Journal of Business Studies Quarterly, 2(3), 84-93.

Karatepe, O. M., Yavas, U., \& Babakus, E. (2007). The effects of customer orientation and job resources on frontline employees' job outcomes. Service Marketing Quarterly, 29(1), 61-79. http://dx.doi.org/10.1300/J396v29n01_04

Kusluvan, S., Kusluvan, Z., Ilhan, I., \& Buyruk, L. (2010). The human dimension: A review of human resources management issues in the tourism and hospitality industry. Cornell Hospitality Quarterly, 51(2), 171-214. http://dx.doi.org/10.1177/1938965510362871

LePine, J. A., Erez, A., \& Johnson, D. E. (2002). The nature and dimensionality of organizational citizenship behaviour: A critical review and meta-analysis. Journal of Applied Psychology, 87(1), 52-65. http://dx.doi.org/10.1037/0021-9010.87.1.52

Ma, E., \& Qu, H. (2011). Social exchanges as motivators of hotel employees' organizational citizenship behavior: 
The proposition and application of three-dimensional framework. International Journal of Hospitality Management, 30(3), 680-688. http://dx.doi.org/10.1016/j.jhm.2010.12.003

Moon, H., Kamdar, D., Mayer, D. M., \& Takeuchi, R. (2008). Me or we? The role of personality and justice as other-centered antecedents to innovative citizenship behaviors within organizations. Journal of Applied Psychology, 93, 84-94. http://dx.doi.org/10.1037/0021-9010.93.1.84

Morrison, E. W. (1996). Organizational citizenship behavior as a critical link between HRM practices and $\begin{array}{llll}\text { service } \quad \text { quality. Human } & \text { Resource }\end{array}$ http://dx.doi.org/10.1002/(SICI)1099-050X(199624)35:4<493::AID-HRM4>3.0.CO;2-R

Murphy, G. C., Athanasou, J., \& King, N. (2002). Job satisfaction and organizational citizenship behaviour: A study of Australian human-service professionals. Journal of Managerial Psychology, 17(4), 287-297. http://dx.doi.org/10.1108/02683940210428092

Nasurdin, A. M., \& Ramayah, T. (2003) The linkage between procedural justice, perceived organizational support, and extra-role citizenship behavior. The Proceedings of the $5^{\text {th }}$ Asian Academy of Management Conference. Kuantan, Pahang, Malaysia.

Nickson, D. (2007). Human Resource Management for the Hospitality and Tourism Industries. Oxford: Butterworth-Heinemann.

Organ, D. W. (1988). Organizational Citizenship Behavior: The Good Soldier Syndrome. Lexington: Lexington Books.

Podsakoff, P. M., MacKenzie, S. B., \& Bommer, W. H. (1996). Transformational leader behaviors and substitutes for leadership as determinants of employee satisfaction, commitment, trust, and organizational citizenship behaviors. Journal of Management, 22(2), 259-298.

Purcell, J., \& Hutchinson S. (2007). Front-line managers as agents in the HRM-performance causal chain: Theory, analysis and evidence. Human Resource Management Journal, 17(1), 3-20. http://dx.doi.org/10.1111/j.1748-8583.2007.00022.x

Ramachandran, Y., Jordan, P. J., Troth, A. C. \& Lawrence, S. A. (2011). Emotional intelligence, emotional labor and organisational citizenship behaviour in service environments. International Journal of Work Organisation and Emotion, 4(2), 136-157. http://dx.doi.org/10.1504/JJWOE.2011.044594

Raub, S. (2008). Does bureaucracy kill individual initiative? The impact of structure on organizational citizenship behavior in the hospitality industry. International Journal of Hospitality Management, 27(2), 179-186. http://dx.doi.org/10.1016/j.ijhm.2007.07.018

Rousseau, D. M., \& Greller, M. M. (1994). Human resource practices: Administrative contract makers. Human Resource Management, 33(3), 385-401. http://dx.doi.org/10.1002/hrm.3930330308

Schneider, B., \& Bowen, D. E. (1985). Employee and customer perceptions of service in banks: Replication and extension. Journal of Applied Psychology, 70(3), 423-433. http://dx.doi.org/10.1037/0021-9010.70.3.423

Schlechter, A. F., \& Engelbrecht, A. S. (2006). The relationship between transformational leadership, meaning and organizational citizenship behavior. Management Dynamics, 15(4), 2-16.

Tang, T. V. \& Tang, Y. Y. (2012). Promoting service-oriented organizational citizenship behaviors in hotels: The role of high-performance human resource practices and organizational social climates. International Journal of Hospitality Management, 31(3), 885-895. http://dx.doi.org/10.1016/j.ijhm.2011.10.007

Tourism Malaysia. (2011). Malaysia Hotels and Room Supply. Retrieved from http://corporate.tourism.gov.my

Tourism Malaysia. (2012). Malaysia Hotels and Room Supply. Retrieved from http://corporate.tourism.gov.my

Tourism Malaysia. (2013). Malaysia Tourism Key Performance Indicator. Kuala Lumpur: Ministry of Tourism.

Tsaur, S. H., \& Lin, Y. C. (2004). Promoting service quality in tourist hotels: The role of HRM practices and service behavior. Tourism Management, 25(4), 471-481. http://dx.doi.org/10.1016/S0261-5177(03)00117-1

Wang, Y. (2006). Strategic employee training and development in Chinese luxury hotels. Tourismos: An International Multidisciplinary Journal of Tourism, 1(1), 111-118.

\section{Copyrights}

Copyright for this article is retained by the author(s), with first publication rights granted to the journal.

This is an open-access article distributed under the terms and conditions of the Creative Commons Attribution license (http://creativecommons.org/licenses/by/3.0/). 